\title{
The challenges and opportunities of a global health crisis: the management and business implications of COVID-19 from an Asian perspective
}

\author{
Yipeng Liu ${ }^{1,2} \cdot$ Jong Min Lee ${ }^{1} \cdot$ Celia Lee $^{3}$
}

Published online: 12 May 2020

(c) Springer Nature Limited 2020

\begin{abstract}
On March 11, 2020, the World Health Organization (WHO) declared the coronavirus (COVID-19) outbreak a pandemic. As the evolution and implications of the COVID-19 crisis are still unfolding, we posit that exploring the experiences and strategic responses of Asian countries may shed light on ways to combat COVID-19 for the rest of the world. In this paper, we first articulate the importance of resilience, strategic agility, and entrepreneurship in the context of the fight against COVID-19. Then, with the focus on China, South Korea, and Singapore, we discuss the impact COVID-19 is having on economies and businesses, governmental support for businesses and societies, and implications for global supply chain disruptions. We hope that the global health system will recover quickly, and that the world economy will be revitalized with the contributions and collaboration of science (including social science), industry, and governments.
\end{abstract}

Keywords COVID-19 · Global health crisis · China · South Korea · Singapore · Impact on economies and business · Government support - Global value chain

\section{Introduction}

On March 11, 2020, the World Health Organization (WHO) declared the coronavirus (COVID-19) outbreak a pandemic. COVID-19 has cost hundreds of thousands of human lives globally, presented healthcare professionals with pressing challenges, and exposed the weaknesses of national health systems worldwide. Furthermore, it has swiftly caused significant disruption to economies and societies

Yipeng Liu

Yipeng.Liu@Henley.ac.uk

1 Henley Business School, University of Reading, Reading, UK

2 Shanghai Institute of Technology, Shanghai, China

3 National Technological University, Singapore, Singapore 
on an unprecedented scale (Gibson 2020). As the evolution and implications of the COVID-19 crisis are still unfolding, we posit that exploring the experiences and strategic responses of Asian countries may shed some useful light on ways to combat COVID-19 for the rest of the world. We hope that the global health system will recover quickly, and that the world economy will be revitalized with the contributions and collaboration of science (including social science), industry, and governments (Pereira et al. 2020).

The management of a global health crisis is a complex affair. It requires individual, organizational, and institutional responses and large-scale coordination involving interdisciplinary and multidisciplinary approaches. The Chinese word for 'crisis' (危机weijī̄) is particularly effective in unpacking its notion; it is made up of the two words Wei (危=crisis) and Ji (机= opportunity), indicating the positive aspect inherent in perceiving and responding to a crisis. To effectively deal with a crisis, we need resilience. To effectively capitalize on the opportunities it presents, we need appropriate (and often new) organizational capabilities, innovation, and entrepreneurship. In this paper, we first briefly explain the implications of resilience, strategic agility, and entrepreneurship in the context of the fight against COVID-19. Then, with the focus on China, South Korea (hereafter Korea), and Singapore, we discuss the impact COVID-19 is having on economies and businesses, governmental support for businesses and societies, and global supply chain disruptions. To conclude, we discuss two trends for the future due to COVID-19: the decoupling from China's supply chains and the relocation of strategic manufacturing operations out of China, and its implications for business and society.

\section{Resilience, strategic agility, and entrepreneurship in combating a global health crisis}

\section{Resilience for and from all}

When any unprecedented global health challenges and large-scale shocks strike, resilience is in great demand. Importantly, it is needed by individuals, organizations, and society to survive and thrive in the face of the fight against the virus and the associated economic and societal shocks. In tackling a global health crisis, resilience requires not only psychological readiness but also organizational support and system-level preparation. Research has shown that occupational contexts can play an important role in enabling both individuals and organizations to build resilience and develop effective coping strategies (Liu et al. 2019). Healthcare professionals are on the frontline in delivering medical treatment to patients under enormous stress; thus, it is critical to prepare those professionals to build resilience in their interactions with patients and other stakeholders. Besides, the salience of cultural differences should be carefully considered and incorporated in the design of any interventions aimed at building resilience in individuals, organizations, and society at large (Liu 2020). We need to collectively 'bounce back'; as a whole, we will become stronger in the process of combating COVID-19 and launching 'new norms' for our organizations and societies. To echo the inspirational words of Winston Churchill, 
"Success is not final, failure is not fatal; it is the courage to continue that counts", we need the courage, willingness, and ability to build and amplify resilience and rebuild our confidence and trust in global health systems.

\section{Strategic agility and organizational capabilities}

Strategic agility is critical for business enterprises and organizations to deal successfully with this grand societal challenge. They need to cultivate the capabilities and skills required to swiftly transform their business and management practices in dealing with a global health crisis. Large corporations need to reinvent themselves and make a swift transition to focus on the creation of value for both business and society and support their agile adaptation to the global value chain changes brought about by the disruption of transportation, logistics, and the mobility of people and resources (Kano et al. 2020). Small and medium enterprises (SMEs) can leverage their flexibility and agility in responding to market needs and societal demandssuch as the production of personal protective equipment (PPE) — by quickly adjusting their production base (Xing et al. 2020). Furthermore, industrial sectors, either manufacturing or services, should respond rapidly by building on the strength of their own particular characteristics. They need to collaborate with governments to maximize the effects of the various stimulus packages and crisis rescue schemes. The current crisis may provide manufacturing firms with opportunities to transition to the provision of services in response to the changes in consumer behaviors while capitalizing on the dynamics of global export markets ( $\mathrm{Li}$ et al. 2019). It is worth noting that the organizational capabilities associated with strategic agility are not simply related to resource readiness and allocation; they require coordination mechanisms to be in place to activate and materialize both resources and knowledge bases (Liu and Huang 2018). For instance, the novel concept of Fangcang shelter hospitals entails that Asian countries should possess the organizational capabilities suitable to build and operate them in response to public health emergencies (Chen et al. 2020).

\section{Entrepreneurship and innovation for creative solutions}

In this age of uncertainty linked to the current global health crisis, entrepreneurship can provide creative solutions by pooling the knowledge and wisdom of entrepreneurs and innovators across geographical boundaries. In particular, to snatch opportunity (Ji) from the jaws of the crisis, entrepreneurs can find and create new opportunities across multiple sectors-commercial, social, and governmental-to address the grave issues faced by societies worldwide. For instance, hospitals, as hybrid organizations, need to accommodate multiple institutional logics in China, while cross-sector collaboration and partnerships can promote the process of Chinese healthcare reform (Xing et al. 2018) in an inclusive approach that draws upon the beauty and power of entrepreneurship to achieve sustainable regional development and economic transformation (Kraus et al. 2020). International organizations around the world are in a race against time to find effective solutions to curb the spread of the virus and eventually vanquish it. The United Nations is calling for 
innovative, scientific, and technological solutions suited to address the COVID-19 pandemic and its associated impacts. Despite its negative impacts, the COVID-19 crisis presents unique opportunities for entrepreneurs to come up with creative disruption for the benefit of individuals, organizations, and society. For instance, given the urgent quest for indigenous innovation and industry transformation, in China, returnee entrepreneurship is conducive to foster a mass entrepreneurship and innovation movement (Froese et al. 2019).

\section{Turning crisis into opportunity}

In the early stage of the COVID-19 outbreak, Korea was facing a huge crisis. At one point, it was the second largest country in terms of numbers of confirmed cases. This was partly due to its geographic proximity to China and partly to a large-scale community infection. However, Korea managed to slow down the spread and is making its best efforts to prevent a second wave of infections. While doing so, Korea is also proactively driving initiatives aimed at turning this crisis into an opportunity. In the course of their fight with the virus, the Korean government and businesses developed a variety of innovative prevention measures (e.g., drive-through testing) and products (e.g., testing kits) that can be utilized all over the world. Many Korean manufacturers also took the chance to reconsider and restructure their global supply chains in order to make them more sustainable. Both the governmental and business sectors see clear growth opportunities in non-contact industries, including telecommunication, online education, and remote support solutions. Companies can enhance their reputation and contribute to alleviating the negative impacts of the global health crisis by implementing corporate social responsibility initiatives. Many Korean multinationals, for example, have embarked in providing support to secure the supply of medical devices and protecting employees in developing countries with weak medical infrastructure. In short, resilience, strategic agility, and entrepreneurship will continue to play a key role in capturing value from these opportunities while overcoming the crisis.

\section{Impacts on economies and businesses}

In addition to its awful cost in human lives, the COVID-19 outbreak is creating huge economic disruption, especially in the highly connected modern world, in which both trade and foreign investments are increasingly globalized and the majority of the population is urbanized. Previous research on economic epidemiology has provided useful insights into theoretical models suited to analyze potential influenza pandemic events (Geoffard and Philipson 1996; Gersovitz and Hammer 2004). These studies have examined the links between the epidemiology and dynamics of a disease, the behavioral responses of people in reaction to a disease outbreak, and the economic consequences of both such behavioral responses and the disease (Brahmbhatt and Dutta 2008). Infectious disease outbreaks typically incur both direct and indirect costs. The former refers to the resources required to cope with the disease 
itself, such as expenditures for medical care and treatment. The latter concerns the present and future costs levied on society by morbidity and disability; in particular, the losses of output caused by reductions in productivity or in the available workforce.

Over the past few decades, experience with infectious diseases (such as SARS and MERS) has revealed that the bulk of the economic costs can actually be ascribed to the preventive behaviors adopted by individuals and the transmission control policies enacted by governments, while the costs associated with direct medical activities and the actual illness are rather limited (Brahmbhatt and Dutta 2008). This is consistent with what is being observed in the case of the COVID-19 pandemic, despite its impact seeming unprecedented in terms of both direct and indirect costs. As the virus spreads internationally, many countries took action to limit the spread through social isolation or physical distancing policies. A number of countries, including the world's largest economies, have asked most, if not all, of businesses to shut down and have restricted people's opportunities for aggregation and mobility. Such preventive actions have had an immediate and significant impact on both the domestic and international economies (Maliszewska et al. 2020).

The massive lockdowns and distancing measures enacted in various countries immediately scaled back both production and consumption. In their efforts to stop the spread of the virus, countries have also partially or fully closed their borders, which also hinders the flow of goods, capital, and people. This has significantly reduced the international flow of goods and services and has simultaneously disrupted global supply chains. In the wake of these measures, most countries have already begun to experience a macroeconomic hit caused by the pandemic. Less than three months into the COVID-19 crisis, economists have reached a consensus that the world has been plunged into a global recession (Giles et al. 2020).

It is too early to assess the potential ultimate impact that COVID-19 will have on the global economy as well as on those of individual countries. The pandemic is still an ongoing issue and the estimates provided by international institutions such as the International Monetary Fund (IMF) and the World Bank are being revised every week to reflect real-time information. However, previous experience suggests that heterogeneity in national economic structures and trade networks may result in each country facing different consequences. For instance, a recent simulation study conducted by the World Bank suggests that the gross domestic product (GDP) losses due to the pandemic may be more severe in those countries that are the most dependent on trade and/or in which tourism plays a major role in the economy (Maliszewska et al. 2020). According to the IMF, while growth in Asia is expected to come to a standstill in 2020 , there will be substantial downward revisions, ranging from $3.5 \%$ in the case of Korea, which appears to have managed to slow the spread while minimizing prolonged production shutdowns, to over $9 \%$ in the case of Thailand and New Zealand, which are being hit by the global tourism slowdown, and of Australia, which is being hit by lower revenues in both tourism and sales of commodities (Rhee 2020).

As shown in Table 1, China, Korea, and Singapore have different characteristics in terms of their economic and trade structures, not to mention size and population. Although the economic impacts of COVID-19 are expected to be unprecedentedly 


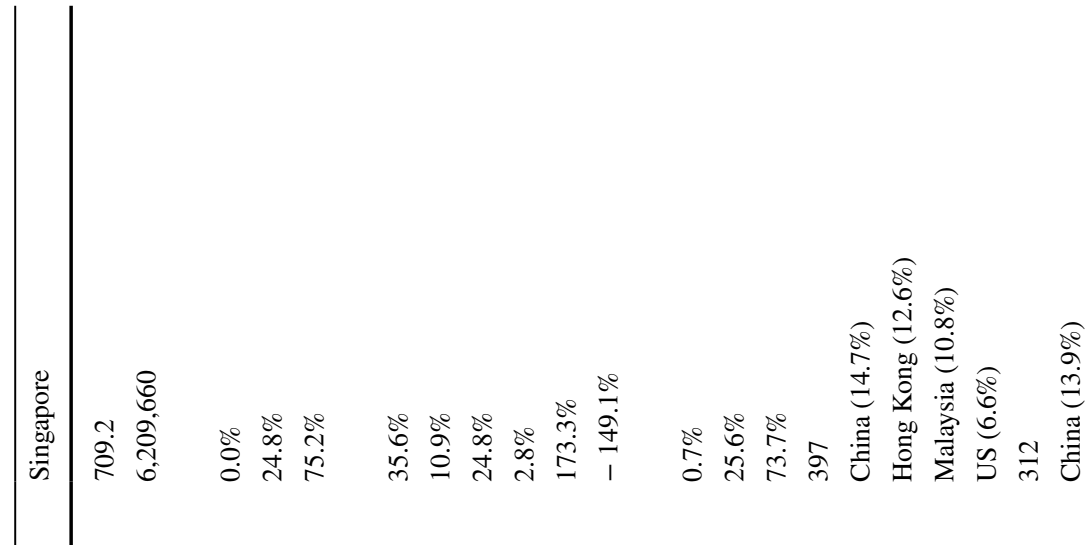

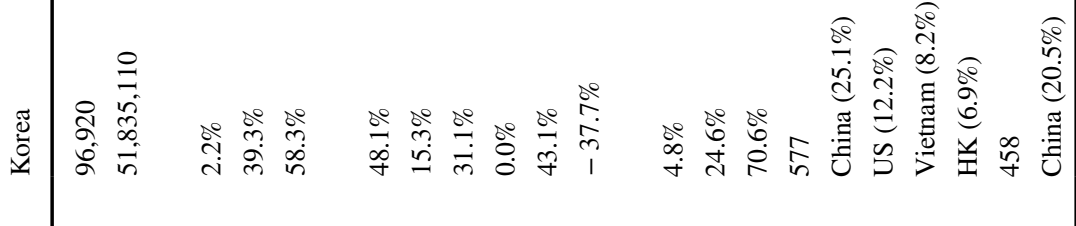

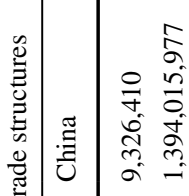

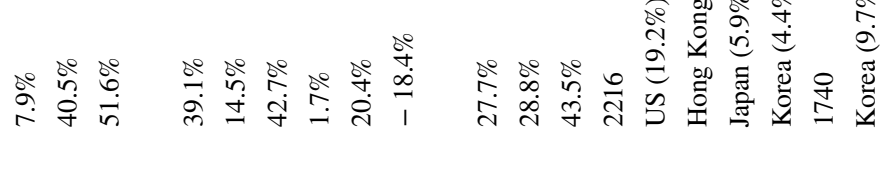

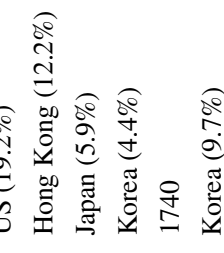
.

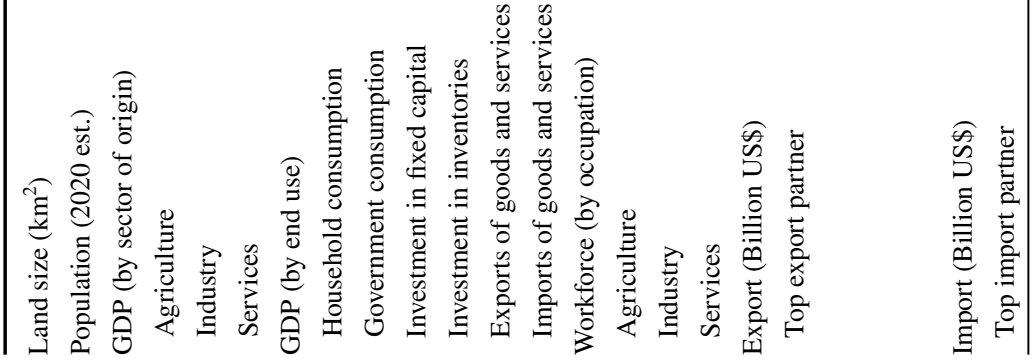

赎。 


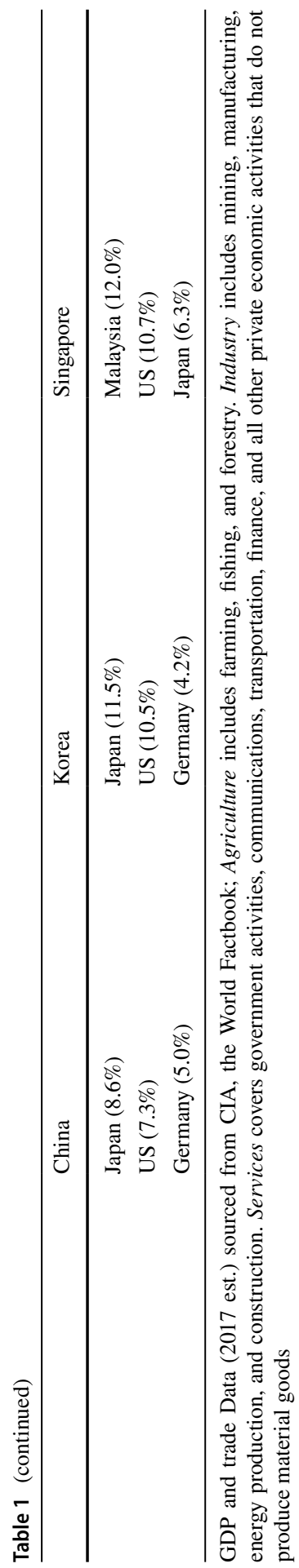


severe in all three countries, the main challenges faced by each may vary considerably depending on the different specificities presented by their respective contexts. China is being mostly affected by the fall in industrial production linked to the shutdown of factories. As is widely recognized, China has for some time taken on the role of the world's largest workshop and exporter. Accordingly, national factory shutdowns are creating massive knock-on effects on the world's trade and production by disrupting global supply chains. For instance, immediately after the Chinese factory shutdowns, electronic component prices increased sharply due to supply shortages; this, in turn, has negatively impacted the electronics manufacturing sector across the globe (more details in the next section). Moreover, in addition to its importance in the global economy, China spends more than $40 \%$ of its GDP on investment in fixed capital (i.e., total business spending on fixed assets, such as factories, machinery, equipment, property, and inventories of raw materials) which provides the basis for future production. This indicates that China's slowdown due to COVID-19 is likely to have far-reaching and long-term consequences on the global economy, presenting particular challenges to the global value chain.

Household spending accounts for almost half of Korea's GDP, which forms an important part of the aggregate demand within the country. As with other countries all over the world, the pandemic is hitting household spending hard. The shutdown of businesses and the stern distancing measures enforced by the government have directly led to a sharp decrease in employment and household spending in most countries. Although Korea has hitherto managed to avoid a complete shutdown, it is still facing a sharp contraction in household spending, as many consumers expect their income and savings to decrease (Ho et al. 2020). While such contraction in household spending has triggered a localized shock, the potential major threat to the Korean economy has much to do with the disruption in international trade and global value chains. Korea is a trade-oriented and export-dependent economy, and China is its largest trade partner in terms of both export and import. In particular, Korea is the 5th largest export economy in the world, with China accounting for more than $25 \%$ of its exports. Although it varies across industries, many Korean manufacturers export (technology intensive) intermediate goods to China, where they are then assembled into finished products and shipped to their final destinations around the world. While the global pandemic has reduced final destinations demand (e.g., from the US and Europe), the huge potential impact of COVID-19 on the Korean economy would be linked to the disruption in its exports of value-added intermediate goods to China.

Singapore would also suffer severely from supply chain disruptions. The country also exports highly differentiated intermediate goods to China, and its exporters would find it difficult to redirect their trade elsewhere. However, given that Singapore's added value from gross exports is relatively low, as is the country's share of GDP from its industrial sector, the effects from the manufacturing-supply chain disruption may be, to some extent, mitigated. The more critical economic challenge for Singapore may be related to its high dependency on its services sector which accounts for more than $75 \%$ of the country's total GDP. Indeed, the pandemic is having its severest effects on aviation, travel, and tourism, which account for a substantial portion of the Singaporean economy. This impact is already quite evident; in 
the first quarter of 2020, Singapore's GDP shrank by $10.6 \%$, a sharp pullback from the $0.6 \%$ growth recorded in the previous quarter (MTI 2020). The national Ministry of Trade and Industry also downgraded Singapore's forecast GDP growth to between -0.5 and $1.5 \%$. This is the worst GDP contraction forecast since the global financial crisis in 2008 and also for the first-time the manufacturing, service, and construction sectors are expected to contract since the 1998 Asian financial crisis. Moreover, as demonstrated by its high GDP spending on the exports and imports of goods and services, the Singaporean economy cannot be sustained by the country's domestic workforce alone; it requires foreign (non-resident) workers, 300,000 of whom are being isolated and not allowed to work due to outbreaks in dormitories and construction sites. This will inevitably have substantial negative effects on Singapore's economy.

In short, although COVID-19's actual economic impact will be difficult to assess until the pandemic is over, each country will be certainly affected differently, depending on its economic and trade structure. Moreover, while much of the impact depends on the spread of the virus and on how governments respond, different countries are currently experiencing different stages of the pandemic. China's economy is beginning to spin up, while many others are still maintaining tighter lockdowns. Singapore is experiencing a second wave of virus infections due to the large-scale community infection radiating from the foreign workers' dormitories. Korea has managed to slow the spread, but still enforces tight social distancing measures in order to minimize the likelihood of a second wave of infections. Therefore, business managers and policymakers are faced by the need to devise appropriate strategies and policy measures to fit different contingencies. At the same time, they need to take into account that the various industries, agents, and markets in the global economy are interdependent and may, therefore, reciprocally exchange knock-on effects, with a time lag across countries.

\section{Government support for business and society}

So far, the pandemic has brought instant disruption to economic activities across the world, as is evidenced by the decline in tourism flows, the virtual stoppage of air travel, and a weakening of consumer and business confidence. To contain the virus, most countries have imposed lockdowns, community quarantines, stay-athome orders, temporary business closures, and travel restrictions or prohibitions. To help allay the financial burden on businesses and support badly affected industries, governments and central banks worldwide have enacted a wide range of emergency measures and relief packages. These measures range from employee protection to sizable financial stimulus and tax incentives. In an effort to mitigate the economic impacts of COVID-19, the USA, the world's largest economy, has passed a US\$2 trillion economic stimulus package, the largest in US history. From Singapore to Japan, other governments are also deploying billion-dollar rounds of fiscal stimulus to minimize the economic pain for both businesses and households.

As Fig. 1 shows, the IMF expects no growth in Asia in 2020. This would be the worst performance in almost 60 years, including during the Global and Asian 


\section{Real GDP Growth}

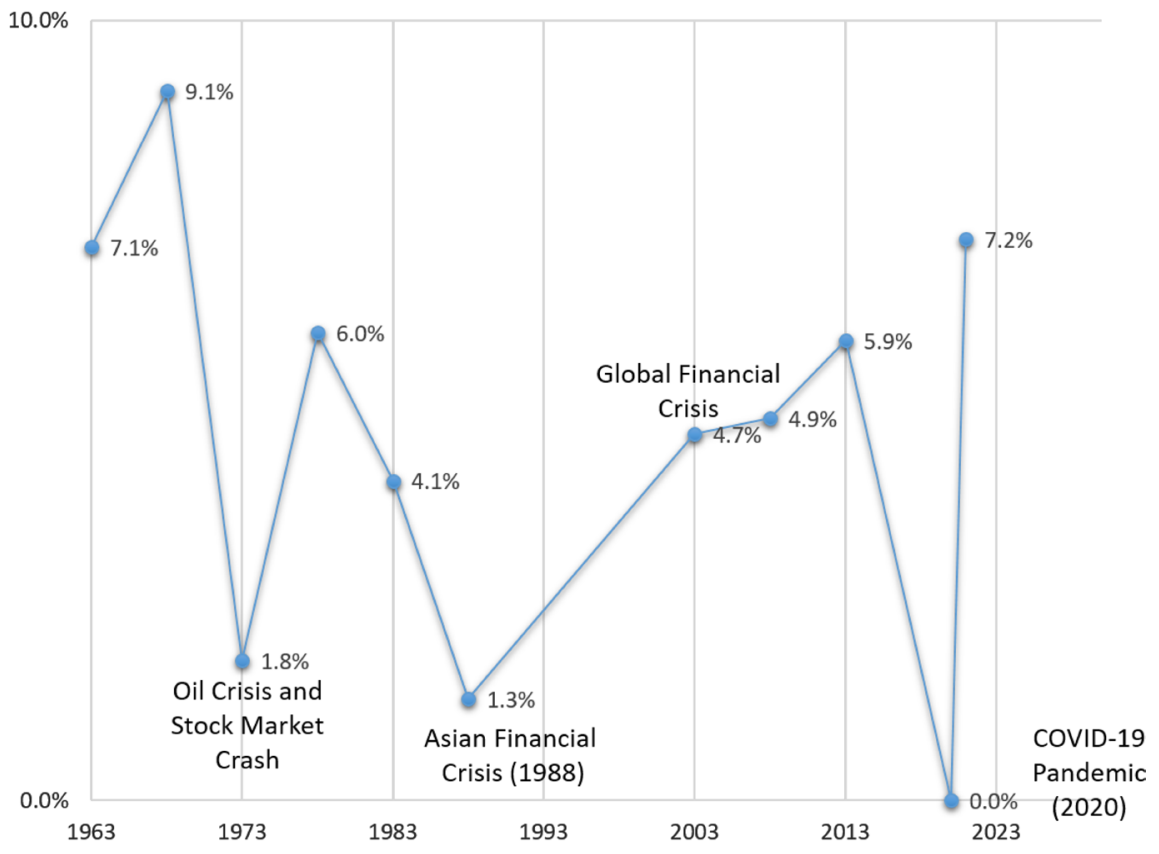

Note: adapted from IMF, Rhee 2020

Fig. 1 Growth in Asia in 1963-2021. ) Source: adapted from IMF, Rhee (2020

Financial Crises (when $4.7 \%$ and $1.3 \%$ were recorded, respectively). The global and Chinese slowdowns are the two key factors that are shaping the outlook for Asia. The global economy is expected to contract by $3 \%$ in 2020, while Asia's key trading partners, the USA and the EU (European Union), are expected to contract by $6 \%$ and $6.6 \%$, respectively. On the other hand, China's growth is projected to shrink from 6.1 to $1.2 \%$ (Rhee 2020 ).

Since the early onset of the pandemic, even before the WHO declared COVID-19 as a global pandemic, Asia-Pacific policymakers had already begun to provide fiscal stimulus to bail out the aviation industry, which has come to a virtual standstill with the many closed borders and restrictions on travel. Global airlines are on the hook for US $\$ 35$ billion in refunds for unused tickets, worsening a cash crunch that is likely to bankrupt some carriers (Lee 2020). When the crisis that led to lockdown in Wuhan and movement controls many areas in China first broke, Korea announced that it would make US\$240 million worth of low-cost loans available to airlines (MLIT 2020). While Singapore government has pledged US\$525 million to support its grounded aviation sector through two schemes-i.e., a job scheme to subsidize the workers' monthly wages and an enhanced aviation support package aimed at providing relief to the businesses in the sector, China, on the other hand, provides subsidies (US\$0.0025 per seat kilometer for shared flights and US\$0.007 per seat kilometer for solo flights) only to those airlines that did not suspend or have resumed 
international flights. Air companies that operate important emergency flights will also receive special subsidies to cover their costs (MFPRC 2020).

Since its first confirmed cases in late January/early February, both the Korean and Singaporean government have been determined and quickly responded to contain the virus. Subsequently, due to the increases in imported cases and local transmission - which, in the case of Korea, spiked to more than 2300 cases in just 10 daysmore stringent measures, such as enhanced social distancing measures, stringent inbound and outbound travel restrictions, school closures, massive testing and contact tracing campaigns, self-isolation, and quarantine orders have been implemented. While Singapore was praised at the beginning for its efficient approach to contain the outbreak, it has seen infections spike, with clusters emerging among migrant workers, which led to partial lockdown/circuit breaker measures (with only essential services remaining unaffected) announced from 6th April to 4th May 2020 (then extended to 1st June 2020) to combat the spike in unlinked community transmission. In line with those measures that will further strain the economy, both the Korean and Singaporean governments have unveiled urgent stimulus packages, summarized in Table 2, to address healthcare costs, household expenditure, unemployment, small and medium enterprises, childcare, and so on.

Even as Korea has showcased its success in managing the COVID-19 outbreak without a draconian lockdown and while keeping many businesses and factories open, the global economy is sinking into a severe recession and Korea's dependent economy is consequently facing tsunami-like shockwaves (Bae 2020). As of April 2020, a total of four stimulus packages totaling US $\$ 122.8$ billion have been announced to boost the domestic market and export industries in order to cushion the blow of the employment crisis and liquidity crunch, besides stimulating local consumption by maximizing advanced payments to inject liquidity. To boost domestic spending, the government is also making advanced payments for those public investment projects that were slated for the second half of the 2020. In addition, the government aims to create about 500,000 new jobs in the public sector. To fund the extra budget, an additional US $\$ 8.5$ billion in treasury bonds will be issued this year.

Within a span of 2 months (February to April 2020), Singapore has announced three economic stimulus packages amounting to S $\$ 59.9$ billion (US $\$ 42.8$ billion), which constitutes $12 \%$ of the country's GDP, and encompasses the unity, resilience, and solidarity budgets (Sim 2020). In addition, the government has also provided grants to the food sector to provide delivery services and invest research and development capabilities to develop test kits and ensure food security. The government has also introduced a COVID-19 (Temporary Measures) Act to offer temporary relief to those businesses and individuals who are unable to fulfill their contractual obligations due to the virus. The provisions in this Act have also come into effect on 20 April 2020. This Act relates to temporary exemption from legal action for inability to fulfill certain contracts as well as increased thresholds for bankruptcy and insolvency for financially distressed individuals and businesses. Ever since the massive outbreak in the foreign workers' dormitories, the government has also deployed support teams to address the workers' essential needs by setting up medical facilities and triage clinics, bringing in supplies and food, as well as managing logistics and housekeeping. All construction and infrastructure projects have also been placed on 


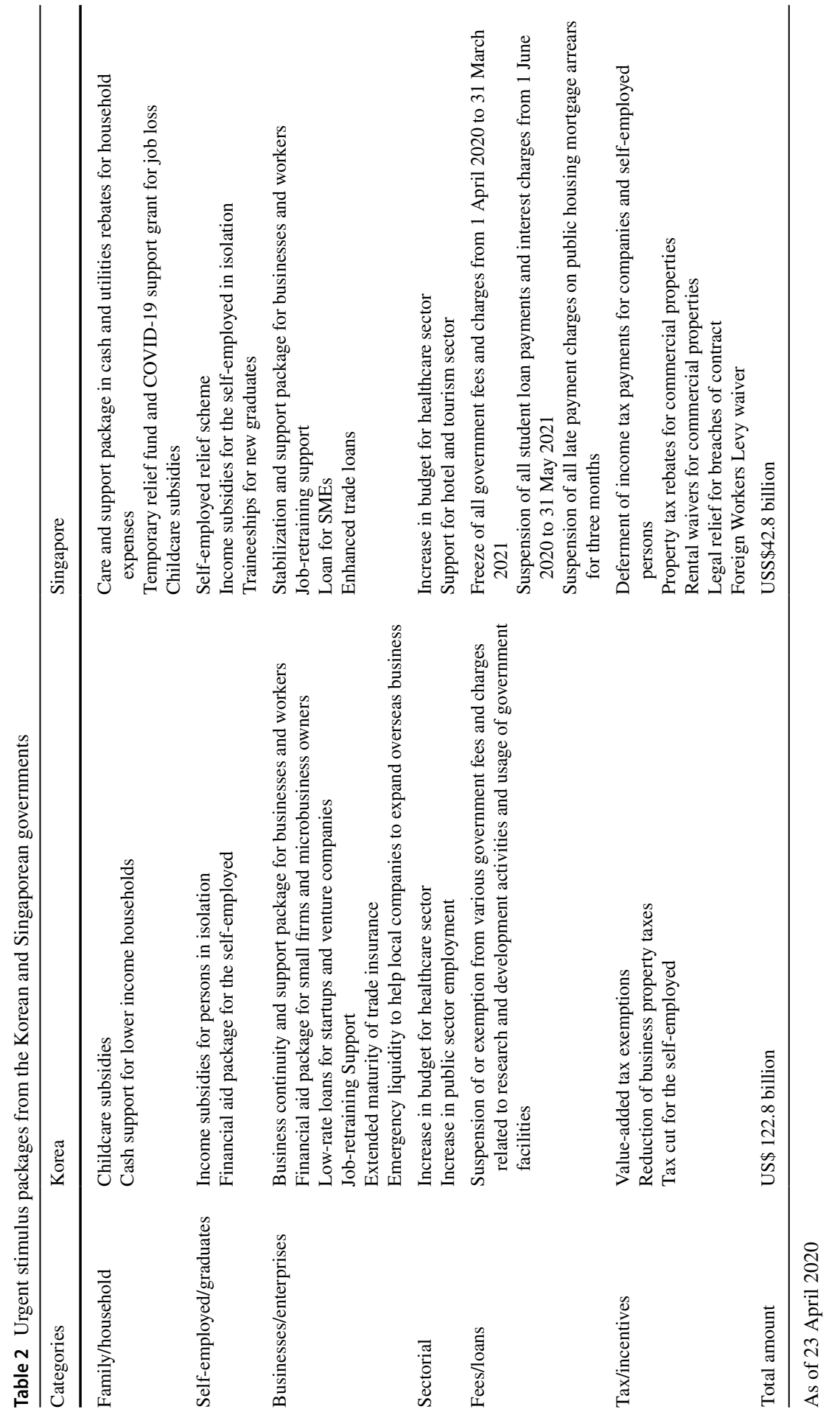

我造 
hiatus to prevent further transmission of the virus, while ensuring continued wages for all foreign workers.

To stop the spread of the virus, the Chinese government has enacted aggressive measurements such as the lockdown of the heaviest affected regions (including Wuhan), suspensions of public gatherings, the mass isolation of infected patients, prohibitions on travel, and home quarantines. These measurements have taken a toll on China's domestic economy that could impact international trade and global production networks and value chains, and that could trigger global turbulence and a catastrophe in the financial markets. As summarized in Table 3, China's package of policies can be largely grouped into during- and post-outbreak ones. During the outbreak period, the government's economic policies were primarily aimed at supporting antivirus manufacturing, transportation, services, and retail sectors. Conversely, for the post-outbreak period, they are more focused on supporting the resumption of work and production and on boosting domestic spending.

As part of its focus on restarting the economy after the pandemic, the central government has also required local governments to simplify business approvals and optimize services. To expand domestic demand, several ministries are also seeking to stimulate infrastructure investment in a number of projects related to the energy, transportation, and information technology (5G) industries. To stabilize international trade and foreign investment, the central government has ensured the full and timely payment of export tax rebates, with the exception of energy-intensive, polluting, or resource-heavy products, and financial institutions are being encouraged to increase foreign trade credits, defer loan payments, and extend debt rollovers for small trading firms. To mitigate the adverse impact of the pandemic as per the rolled out measurements, an additional central bank credit line of $¥ 1$ trillion (about US\$140 billion) will be extended and fund will also be raised through issuance of an additional $¥ 1.85$ trillion (US\$ 259 billion) of local government bonds.

As the global containment measures are severely affecting economies, there is a need for targeted support to the hardest-hit households and sectors to protect jobs and industries. Asian economies-like Korea, Singapore, and China-have taken several initiatives in this direction, especially to ease the financial stress of the aviation and tourism industries and SMEs. Among the three countries, Singapore's stimulus packages are the most comprehensive. Bracing for a recession, the government will draw $\mathrm{S} \$ 21$ billion (US\$15 billion) from its national reserves to sustain the economy which will be further strained by the circuit breaker measurements. Korea, in comparison to other countries, was able to avoid a complete lockdown and minimize the impact, its stimulus package is more focused on directly affected sectors and individuals under isolation. Further injections of funds into the economy are aimed at helping with unemployment and boost domestic spending. So far, China has not unveiled a targeted economic plan, but has opted to inject funding into banks and local government in the hope that it will trickle down to small businesses and residents. China is stepping up stimulus efforts to help growth, but is largely relying on providing money to local governments to speed up infrastructure investment, rather than distributing direct handouts to households or conducting broad-based tax cuts for businesses and individuals like Korea and Singapore. To ensure that these various stimulus packages produce the best outcome, governments must avoid incurring 


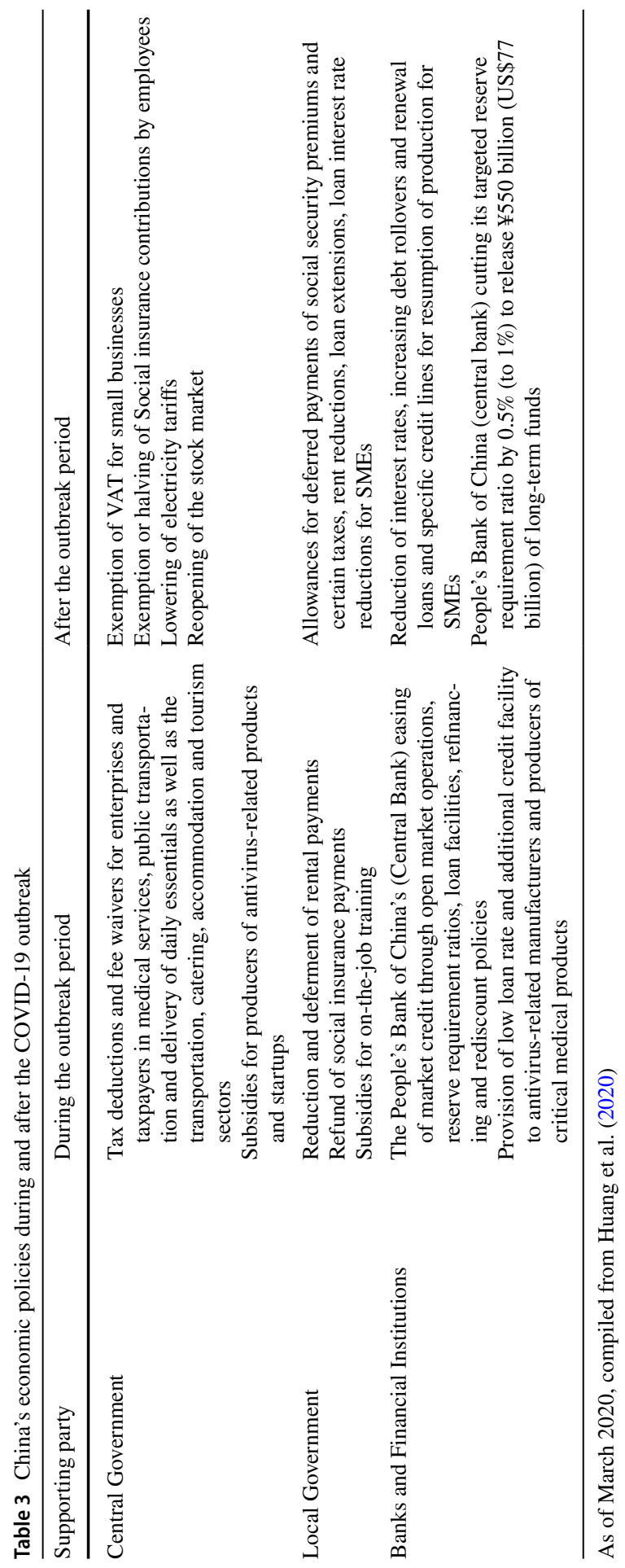

2. 
in 'policy fatigue', whereby fiscal measures do not work as expected. Governments must recognize the limited effectiveness of stimulus packages. Stimulus packages can only help to cope with short-term challenges and strengthen economic and social resilience. They would not address the structural issues that are affecting job security during recession as fiscal and monetary policies alone cannot re-establish broken supply chains, bring people back to shopping malls, or reboot air travel. The main thrust should be directed to restoring public confidence by effectively containing the virus, making it possible to safely put an end to lockdowns and movement restrictions. Even when restrictions are lifted and governments undertake more infrastructure projects to help businesses, it will take time to draw up the necessary contracts and to get the required approvals before any funding can be channeled to the businesses involved. Government should be mindful to streamline processes and cut down red tapes to facilitate resumption of work within a shorter time frame.

\section{Global supply chains and business collaboration}

The disruption in global supply chains is a major issue associated with the economic costs of COVID-19 pandemic. In particular, it has much to do with the breakout having its epicenter in China which has been functioning as the world's manufacturing hub in various sectors. Over the past few decades, multinational enterprises (MNEs) have increasingly fragmented their production networks to take advantage of locational advantages and a global production scale. Advances in information and communications technology (ICT) and international transport networks have allowed MNEs to more easily fine slice their value chain activities, optimize and coordinate the location of specific sets of activities across borders, and de-internalize those business activities that were considered less critical (Dicken 2011; Rugman et al. 2011). Accordingly, to achieve systemic efficiency and productivity across entire international production systems, MNEs have relocated their value chain activities to optimal locations. Their production processes have been increasingly interconnected across the vertical trading chain that stretches across many countries, with each country specializing in particular stages of a good's production sequence (Hummels et al. 2001). Since it opened up to the world in 1978 - and relying on its abundant, cheap, and well-disciplined workforce-China has become the world's workshop. Over the past few decades, China has developed its business ecosystem to establish industrial production systems that require networks of suppliers, component manufacturers, distributors, governments, and customers. By moving their low-end production to China, many MNEs from all over the world have attained cost advantages (Buckley 2009).

\section{Impact on the electronics industry}

In 2019, China accounted for over $50 \%$ of global semiconductor consumption (Deloitte 2020). To limit the spread of the virus, critical electronics manufacturing hubs have also been temporarily shut down, which has adversely affected the global 
Table 4 The most impacted sectors and their integration in the global supply chain

Chinese share of global exports Chinese share of (\%) gross output $(\%)$

Computer, electronics, optical products

49

Electrical equipment

28

59

Other machinery and equipment

28

47

Automobiles

5

33

Adapted from McKinsey (2020)

supply chain, impacting both suppliers (through shortages of materials, components, and finished goods) and consumers (due to reduced spending on semiconductordependent products such as consumer electronics and automobiles). Although the full impact on the global economy is still unknown, the fallout across the electronics value chain (from materials to final products) will likely be critical because intermediate products, many of which are produced in China, are deeply integrated in the global technology supply chain, as shown in Table 4.

The areas most affected by the disruption in China's electronics supply chain are also those in which the largest electronics firms are located, ranging from the coastal Guangdong province to the inner Henan province. Although some firms have gradually started to resume production, the reality is that electronics firms based in China are not operating at full capacity, but only between 30 and $50 \%$. This is creating a knock-on effect on global supply chains (especially those dealing with low- to mid-end parts and components). Hubei also plays a significant role in the global supply chain of critical electronics components. The province is the production base of Taiwan's PCB factories, including Taiwan Optoelectronics, Xinxing, Jianding, Nanzi Electric, and Dingying. In Asia, both Korea and Taiwan rely mostly on China for the downstream assembly of finished electronics products. As much as $70 \%$ of the two countries' exports of intermediate goods in the electronics sector are destined for the Chinese market. On the other hand, other less technologically sophisticated Asian countries rely heavily on China for their upstream supply of electronics parts and components. India, Indonesia, Thailand, and Vietnam source $40-60 \%$ of their intermediate goods imports in the electronics sector from Chinese suppliers. The global pandemic has exposed the potential risks to and vulnerability of the electronics and semiconductor industry, challenging it to refashion its global supply chain model (Table 5). Specifically, businesses need to focus on how to minimize supply chain disruptions and to adjust rapidly to a changing landscape by first understanding their risk exposure arising from the origin of supply and the impact on demand to plan supply. Secondly, businesses need to anticipate supply shortages due to unforeseen disruptions in the supply chain (e.g., lockdowns and closing of air or railways) in order to consider other modes of transportation. They will also need to pre-book their freight arrangements to avoid over-congestion of traffic and routes when the restrictions are lifted. Finally, to avoid 'putting all eggs in one basket"', they may consider including more suppliers and sourcing for suppliers from non-China countries. 


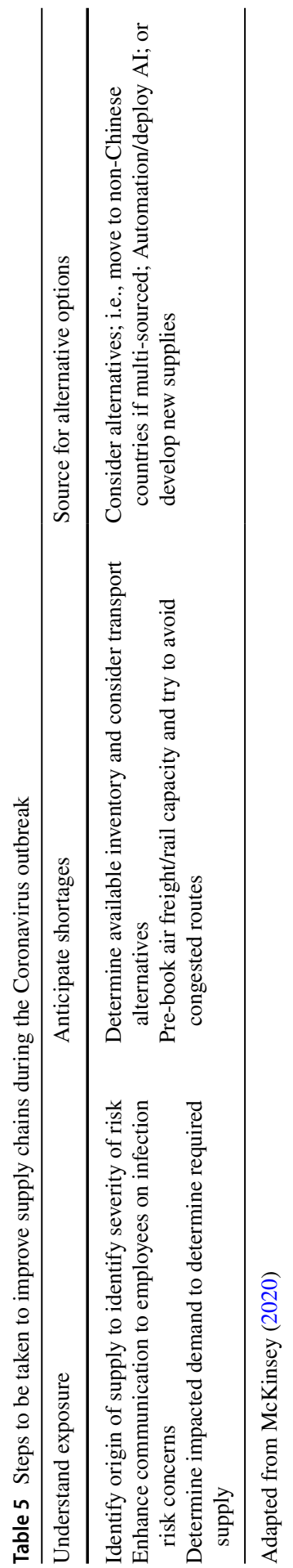


The pandemic has caused some countries to pull their firm's manufacturing activities out of China-e.g., Japan has earmarked US\$2.2 billion of its record economic stimulus package to helping its manufacturers relocate their Chinese production operations (Bloomberg 2020). Pegatron, a Taiwanese key assembler of iPhones with manufacturing sites in China, is also adding production capacity back home in Taiwan. This signals a potential shift in the global production paradigm that has governed the electronics industry for well over three decades.

Although this outward-bound trend is accelerating, it is unlikely that China will give up its place as the world's electronics workshop. This is because of the difficulties involved in replicating the intricate network of suppliers, competent workers, efficient distribution systems, and large market offered by the country. Any large-scale relocation of manufacturing capabilities would also take time.

\section{Impact on the automobile industry}

The disruption affecting global value chains has impacted many Korean manufacturers, particularly those that rely heavily on vertical supply chains located in China. The Hyundai Motor Company, for instance, had to put its production line in Korea on hold not because of the government's shutdown order, but due to the shortage of an essential auto part-a wiring harness - that is procured from China. A wiring harness is an assembly of electrical cables or wires that transmit electrical signals or power. Hyundai procures it from three Korean suppliers, all of which have their production lines in China. As this particular wiring harness is quite large, it is not efficient to stockpile it in large quantities. Therefore, Hyundai usually only stores stock for a week's production and, due to its close geographic proximity to China, relies heavily on just-in-time delivery logistics. Accordingly, the supply chain disruption affected the Korean automaker more and much faster than others (Kim 2020). The shutdown of the production line of Korea's largest automaker is having significant knock-on effects on the national and regional economies, as all other suppliers and related businesses have also had to stop their production.

\section{Impact on food security}

The pandemic has exposed the fragility of our globalized economy and the tangled complexity of our global supply chains. As an import-driven economy, Singapore is particularly vulnerable to such an unprecedented disruption to international networks, which represents a "good lesson for everyone to look at the supply chain resilience"1. A major concern for Singapore is food supply, as $90 \%$ of food products are imported from 170 countries. To ensure that trade lines are kept open for food and essential items, minimizing disruption and speeding up recovery, a Ministerial Coordination Group on COVID-19 (MCGC)—which was convened by Canada and included the foreign ministers of Brazil, France, Germany, Indonesia, Italy, Mexico,

\footnotetext{
${ }^{1}$ Interview with Mr. Chan Chun Sing, Singapore's Minister for Trade and Industry, 4th February 2020, Squawk Box Asia, CNBC.
} 
Morocco, Peru, Singapore, Korea, Turkey, and the UK-has committed to maintaining global links, such as transport and supply chain connections and to lower tariffs. This signifies global cooperation through close bilateral and multilateral communication and collaboration to mitigate disruption and respond to the development of COVID-19.

\section{Concluding remarks}

In brief, COVID-19 has accelerated two powerful trends for the future: the decoupling from China's supply chains and the relocation of strategic manufacturing operations out of China. Moving forward, there will be an increased need for infrastructure and technical means suited to ensure transparency within global supply chains. There must also be a call for the development of predictive models that take into consideration uncertainties and risk factors in the proactive scheduling and dynamic planning of supply. These predictive models will help corporate decision makers to undertake what-if analyses of various scenarios and to consider whether to integrate automation and artificial intelligence (AI) to increase efficiency. Moving forward, greater collaboration between governments and industries will be needed to ensure minimum disruption in global supply chains (Lim and Lee 2020).We hope that this paper will trigger intellectually stimulating debates and meaningful actions from individuals, organizations, and societiesboth in Asia and beyond-in the global fight against COVID-19.

\section{References}

Bae, H. (2020). South Korea unveils another massive stimulus package against coronavirus, The Korea Herald. Retrieved from https://www.koreaherald.com/view.php?ud=20200408000825. Accessed 24 Apr 2020.

Bloomberg. (2020). Japan to fund firms to shift production out of China. Retrieved from https://www. bloomberg.com/news/articles/2020-04-08/japan-to-fund-firms-to-shift-production-out-of-china. Accessed 24 Apr 2020.

Brahmbhatt, M., \& Dutta, A. (2008). On SARS type economic effects during infectious disease outbreaks., et al. Policy Research Working Paper 4466, The World Bank

Buckley, P. J. (2009). The impact of the global factory on economic development. Journal of World Business, 44(2), 131-143.

Chen, S., Zhang, Z., Yang, J., Wang, J., Zhai, X., Bärnighausen, T., et al. (2020). Fangcang shelter hospitals: A novel concept for responding to public health emergencies. The Lancet, 395(10232), 1305-1314.

Deloitte. (2020). COVID-19: A black swan event for the semiconductor industry? Deloitte Report. Retrieved from https:/www2.deloitte.com/global/en/pages/about-deloitte/articles/a-black-swanevent-for-the-semiconductor-industry-covid-19.html. Accessed 24 Apr 2020.

Dicken, P. (2011). Global shift: Mapping the changing contours of the world economy (6th ed.). London: SAGE Publications.

Froese, F. J., Sutherland, D., Lee, J. Y., Liu, Y., \& Pan, Y. (2019). Challenges for foreign companies in China: Implications for research and practice. Asian Business \& Management, 18(4), 249-262.

Geoffard, P.-Y., \& Philipson, T. (1996). Rational epidemics and their public control. International Economic Review, 37(3), 603-624. 
Gersovitz, M., \& Hammer, J. S. (2004). The economical control of infectious diseases. The Economic Journal, 114(492), 1-27.

Gibson, C. (2020). Guidepost from 'social distancing'to 'care in connecting': An emerging organizational research agenda for turbulent times. Academy of Management Discoveries. https://doi. org/10.5465/amd.2020.0062.

Giles, C., Greeley, B., \& Arnold, M. (2020). Global recession already here, say top economists, Financial Times. Retrieved from https://www.ft.com/content/be732afe-6526-11ea-a6cd-df28c c3c6a68. Accessed 24 Apr 2020.

Ho, J., Kim, A., \& Yamakawa, N. (2020). Survey: Asian consumer sentiment during the COVID-19 crisis. Mckinsey \& Company. Retrieved from https://www.mckinsey.com/featured-insights/asiapacific/survey-asian-consumer-sentiment-during-the-covid-19-crisis. Accessed 24 Apr 2020.

Huang, Y., Lin, C., Wang, P., \& Xu, Z. (2020). Saving China from the coronavirus and economic meltdown: Experiences and lessons. In R. Baldwin \& B. W. Mauro (Eds.), Mitigating the COVID economic crisis: Act fast and do whatever it takes. London: CEPR Press.

Hummels, D., Ishii, J., \& Yi, K.-M. (2001). The nature and growth of vertical specialization in world trade. Journal of International Economics, 54(1), 75-96.

Kano, L., Tsang, E. W., \& Yeung, H. W.-C. (2020). Global value chains: A review of the multi-disciplinary literature. Journal of International Business Studies. https://doi.org/10.1057/s4126 7-020-00304-2.

Kim, D. (2020). Why automakers are affected most from cascade of factory closures in China: China-made wiring harnesses have been kept in small stocks for efficiency, The Korean Herald. Retrieved from https://www.koreaherald.com/view.php?ud=20200205000735. Accessed 24 Apr 2020.

Kraus, P., Stokes, P., Cooper, S. C., Liu, Y., Moore, N., Britzelmaier, B., et al. (2020). Cultural antecedents of sustainability and regional economic development: A study of SME 'Mittelstand' firms in Baden-Württemberg (Germany). Entrepreneurship \& Regional Development. https://doi. org/10.1080/08985626.2020.1713223.

Lee, D., (2020). Coronavirus: as Covid-19 crisis deepens, recovery hopes of battered Hong Kong, global airlines vanish over horizon, South China Morning Post. Retrieved from https://www. scmp.com/news/hong-kong/transport/article/3077905/coronavirus-covid-19-crisis-deepens-recov ery-hopes. Accessed 24 Apr 2020.

Li, R., Liu, Y., \& Bustinza, O. F. (2019). FDI, service intensity, and international marketing agility: The case of export quality of Chinese enterprises. International Marketing Review, 36(2), 213-238.

Lim, G. \& Lee, C., (2020). Catching-up and the way forward in the electronics industry: The case of China (pp. 1-14). NCPA Case Study-2020-01

Liu, Y. (2020). Contextualizing risk while building resilience: Returnee vs. local entrepreneurs in China. Applied Psychology: An International Review, 69(2), 415-443.

Liu, Y., Cooper, C. L., \& Tarba, S. Y. (2019). Resilience, wellbeing and HRM: A multidisciplinary perspective. International Journal of Human Resource Management, 30(8), 1227-1238.

Liu, Y., \& Huang, Q. (2018). University capability as a micro-foundation for the Triple Helix model: The case of China. Technovation, 76-77, 40-50.

Maliszewska, M., Mattoo, A., \& Van Der Mensbrugghe, D. (2020). The potential impact of COVID19 on GDP and trade: A preliminary assessment, Policy Research Working Paper 9211, The World Bank

McKinsey. (2020). Coronavirus COVID-19: Facts and insights report. Retrieved from https://www. mckinsey.com/ /media/mckinsey/business\%20functions/risk/our\%20insights/covid\%2019\%20 implications\%20for\%20business/covid\%2019\%20april\%2013/covid-19-facts-and-insights-april -13.ashx. Accessed 24 Apr 2020.

MFPRC (Ministry of Finance of the People's Republic of China). (2020). Notice on the policy of financial support during the prevention and control of the new coronary pneumonia epidemic in civil aviation transport enterprises. Retrieved from https://jjs.mof.gov.cn/zhengcefagui/202003/ t20200304_3478074.htm. Accessed 24 Apr 2020.

MLIT (Ministry of Land, Infrastructure and Transport). (2020). Government announces 'airline emergency support measures' for Corona-19. Retrieved from https://www.molit.go.kr/USR/ NEWS/m_71/dtl.jsp?lcmspage=8\&id=95083560. Accessed 24 Apr 2020.

MTI (Ministry of Trade and Industry). (2020). MTI downgrades 2020 GDP growth forecast to _- 0.5 to 1.5 Per Cent'. Press release on 17 February 2020. Singapore . Retrieved from https://www.mti. 
gov.sg/Newsroom/Press-Releases/2020/02/MTI-Downgrades-2020-GDP-Growth-Forecast-to-0_5-to-1_5-Per-Cent. Accessed 24 Apr 2020.

Pereira, V., Temouri, Y., Patnaik, S., \& Mellahi, K. (2020). Managing and preparing for emerging infectious diseases: Avoiding a catastrophe. Academy of Management Perspectives. https://doi. org/10.5465/amp.2019.0023.

Rhee, C. Y. (2020). COVID-19 pandemic and the Asia-Pacific region: Lowest growth since the 1960s, IMF Blog: International Monetary Fund

Rugman, A. M., Verbeke, A., \& Yuan, W. (2011). Re-conceptualizing Bartlett and Ghoshal's classification of national subsidiary roles in the multinational enterprise. Journal of Management Studies, 48(2), 253-277.

Sim, D. (2020). Coronavirus: Singapore unveils US\$3.6 billion third stimulus package for battered economy, South China Morning Post. Retrieved from https://www.scmp.com/weekasia/econo mics/article/3078598/singapore-unveils-us36-billion-stimulus-package-third-boost. Accessed 24 Apr 2020.

Xing, Y., Liu, Y., Boojihawon, D. K., \& Tarba, S. (2020). Entrepreneurial team and strategic agility: A conceptual framework and research agenda. Human Resource Management Review, 30(1), 100696.

Xing, Y., Liu, Y., \& Lattemann, C. (2018). Institutional logics and social enterprises: Entry mode choices of foreign hospitals in China. Journal of World Business. https://doi.org/10.1016/j.jwb.2018.11.004.

Publisher's Note Springer Nature remains neutral with regard to jurisdictional claims in published maps and institutional affiliations. 